\title{
Social support and marginalization as determinants of prenatal care in women with social security in Mexico
}

\author{
Maritza Maldonado-Cisneros ${ }^{1}$ and Oswaldo Sinoe Medina-Gómez ${ }^{2,3}$
}

${ }^{1}$ Regional General Hospital 1, Instituto Mexicano del Seguro Social, Querétaro; 2Universidad Nacional Autónoma de México, National School of Nursing and Obstetrics, Ciudad de México; ${ }^{3}$ Instituto Mexicano del Seguro Social, Family Medicine Unit 15, Ciudad de México, Mexico

\begin{abstract}
Introduction: Prenatal care ensures favorable results for maternal-fetal health and, to that end, it must be provided early, periodically, comprehensively and with high coverage. Objective: To find out the social determinants of prenatal care in women affiliated to the Mexican Institute of Social Security during 2014. Method: Cross-sectional study where the association of social conditions, social support and family functioning with inadequate prenatal care was analyzed. A descriptive analysis was performed; hypothesis tests were used with chi-square (95\% level of confidence). The prevalence ratio and Mann-Whitney's $U$-test were estimated to compare medians and logistic regression. Results: Of the interviewed women, $58.1 \%$ had inadequate prenatal care, mainly associated with unplanned pregnancy, poor social support, low level of education and higher marginalization. Not having leaves of absence granted by employers was the main barrier in those women who did not attend health services. Conclusions: There is a need for strategies to be designed and implemented to enable understanding the interaction between different biological and social dimensions of the health-disease process and reduce health inequities that affect pregnant women, in order to achieve good prenatal care and to implement alternative models guaranteeing its efficiency.
\end{abstract}

KEY WORDS: Social determinants of health. Prenatal care. Pregnancy. Maternal-child health services.

\section{Introduction}

Prenatal care has been considered to ensure favorable results for maternal-fetal health, provided it is offered precociously, periodically, comprehensively and with high coverage. ${ }^{1}$

The World Health Organization has recommended for prenatal care programs to be established for all women of the world and implemented the Millennium Development Goals, which were adopted by the international community in the year 2000 in order to reduce maternal mortality by $75 \%$ between 1990 and $2015 .^{2,3}$

The Mexican Official Standard NOM-007SSA2-2010, for the care of the woman during pregnancy, delivery and puerperium, and of the newborn establishes the procedures during prenatal care at health services of the country and the observance of which is mandatory to ensure quality of care. ${ }^{4}$
Between 2000 and 2004, Mexico achieved an annual maternal mortality rate (MMR) of $4 \%$; however, an annual reduction of $7.5 \%$ is required to reach the goal established for $2015 .^{3}$

Some studies highlight the importance of early prenatal care for a good result for the mother and her child, as well as of social determinants, access to services, individual characteristics and interpersonal factors that are related to good prenatal care. . $^{5-10}$

Although prenatal care generates great benefits for women and newborns in terms of morbidity and mortality, not all pregnant women have optimal access to it. Different studies have demonstrated an association between the lack of prenatal care and perinatal mortality; however, quality of care is fundamental in pregnant women attending health services in order to prevent perinatal mortality. ${ }^{11-14}$
Correspondence:

Maritza Maldonado-Cisneros

E-mail: maritza.maldonadoc@imss.gob.mx
Date of reception: 20-06-2016

Date of acceptance: 06-07-2016

DOI://dx.doi.org/10.24875/GMM.M18000127
Gac Med Mex. 2018;154:136-140

Contents available at PubMed www.gacetamedicademexico.com 
It is important recognizing that the efficacy of prenatal care specific programs as a means to reduce mortality in groups of socioeconomically disadvantaged and vulnerable women has not been rigorously assessed..$^{15}$

There is evidence that socioeconomic conditions, pregnancy planning and access to quality health services are determinant for optimal prenatal care to be achieved..$^{16-20}$

Due to the above, the purpose of this investigation was to find out the relationship of social determinants that influence on prenatal care in women with social security in Mexico.

\section{Method}

A cross-sectional, retrospective, observational study was carried out from April to October 2014 at two family medicine units of the Mexican Institute of Social Security that were chosen by convenience. Sampling for patient selection was made using a systematic random probabilistic method. Inclusion criteria were: puerperal women of any age, assigned to the medical units, who attended seeking medical or preventive care or to arrange administrative procedures at different departments that compose the units during the study period. Women with impairments hindering the interview were excluded, and incomplete questionnaires were censored.

After informed consent and authorization of the local research committee were obtained, puerperal women were interviewed, explained the purpose of the study and invited to participate. Data on age, level of education, number of pregnancies, pregnancy planning, marital status, time to get to the medical unit, waiting time for medical care and occupational status were asked. The Duke-UNC scale was used to identify social support, the lifestyle profile PEPS-1 questionnaire was applied as well as the family APGAR to identify family dysfunction. To find out the level of marginalization, the classification indicated by the Distrito Federal Social Development Information System according to the interviewed person area of residence was considered.

When the social security registration number was obtained, information regarding prenatal care was searched in the electronic medical file. Prenatal care was categorized using the Kessner method, which includes the following indicators: number of prenatal consultations and gestational age at the beginning of care.
Statistical program Stata, version 9.0 (Stata Corp., College Station, USA), was used for data analysis. Descriptive analysis was performed for each variable; hypothesis tests were used with the chi-square test at a level of confidence of $95 \%$; as association measures, the prevalence ratio (PR) was estimated, and Mann-Whitney U-test was used to compare medians. Finally, binary logistic regression was used to assess independent contribution of each variable with regard to inadequate prenatal care, with each marginality level being considered.

\section{Results}

A total of 511 women were evaluated, out of which 3 were eliminated for not having completed the questionnaire. Median age was 26 years, with a range of 14 to 43 years. Most had a level of education of secondary school (30.0\%) and lived in high marginalization areas (51.2\%). Of the interviewed women, $52.6 \%$ had a remunerated job. Low social support was shown by $10.2 \%$ of women, and most common marital status was cohabitation (Table 1); $48.8 \%$ of women started prenatal care during the first trimester of pregnancy, $40.6 \%$ at second and $10.6 \%$ at third trimester (Table 1); $58.1 \%$ of interviewed women had inadequate prenatal care (95\% Cl: 53.8-62.4).

Twenty-four percent of women referred having missed at least one scheduled doctor's appointment; the main reason was not having obtained permission at their workplace (24.6\%).

The time to get from home to the medical care unit had a median of 20 minutes, which was similar between women with optimal and inadequate prenatal control ( $p=0.55)$; however, waiting time when attending a medical appointment was longer among women with inadequate prenatal care (median of 120 minutes) with regard to those who had good prenatal care (median of 30 minutes; $p<0.001$ ).

Among social conditions, having low social support was found to be associated with $26 \%$ higher probability of inadequate prenatal care $(95 \% \mathrm{Cl}$ : 1.03-1.52; $p=0.04)$, in comparison with normal social support.

The results showed no significant difference with regard to inadequate prenatal care between women who planned their pregnancy and those who didn't (PR: 1.02; $95 \% \mathrm{Cl}: 0.87-1.19 ; p=0.82$ ). Women with two pregnancies had a protecting factor that reduced the probability of inadequate prenatal control, with a prevalence odds ratio of $0.81(95 \% \mathrm{Cl}:$ 0.67-0.98; 
Table 1. Characteristics of puerperal women attending a primary care unit

\begin{tabular}{|c|c|c|c|c|c|}
\hline Variable & $\frac{\mathrm{n}}{\text { Adequate }}$ & $\frac{n}{\text { Inadequate }}$ & Prevalence ratio $(95 \% \mathrm{Cl})$ & $\infty$ & $p$ \\
\hline \multicolumn{4}{|l|}{ Age } & $\underline{n}$ & \\
\hline$<30$ & 72 & 93 & 1 & 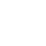 & \\
\hline $25-29$ & 68 & 79 & $0.95(0.57-1.41)$ & $\frac{\varepsilon}{\sigma}$ & 0.64 \\
\hline$>24$ & 73 & 123 & $1.11(0.94-1.32)$ & & 0.28 \\
\hline \multicolumn{4}{|l|}{ Level of education } & 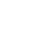 & \\
\hline College degree and more & 67 & 80 & 1 & (c) & \\
\hline High school & 71 & 91 & $1.03(0.68-1.64)$ & & 0.76 \\
\hline Secondary school & 70 & 108 & $1.11(0.92-2.01)$ & $\frac{1}{\alpha}$ & 0.26 \\
\hline Basic education & 5 & 16 & $1.40(0.93-1.85)$ & $\frac{c}{n}$ & 0.06 \\
\hline \multicolumn{4}{|l|}{ Job } & $\frac{\overline{0}}{3}$ & \\
\hline No & 103 & 138 & 1 & 음 & \\
\hline Yes & 110 & 157 & $1.03(0.89-1.19)$ & $\frac{1}{\rightleftarrows}$ & 0.73 \\
\hline \multicolumn{4}{|l|}{ Marital status } & 范 & \\
\hline Married & 100 & 119 & 1 & $\frac{\varsigma}{\circ}$ & \\
\hline Cohabitation & 91 & 137 & $1.11(0.94-1.30)$ & $\bar{n}$ & 0.22 \\
\hline Single & 22 & 39 & $1.18(0.94-1.47)$ & $\underline{\varepsilon}$ & 0.18 \\
\hline \multicolumn{6}{|l|}{ Family functionality } \\
\hline Functional & 111 & 163 & 1 & $\frac{\varsigma}{d}$ & \\
\hline Slight dysfunction & 96 & 115 & $0.92(0.78-1.07)$ & \pm & 0.27 \\
\hline Severe dysfunction & 6 & 17 & $1.24(0.96-1.60)$ & 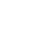 & 0.17 \\
\hline \multicolumn{4}{|l|}{ Social support } & 은 & \\
\hline Normal & 198 & 258 & 1 & 음 & \\
\hline Low & 15 & 37 & $1.26(1.04-1.52)$ & $\stackrel{0}{\simeq}$ & 0.04 \\
\hline \multicolumn{4}{|l|}{ Marginalization degree } & $\stackrel{\rightleftarrows}{丂}$ & \\
\hline Low & 48 & 79 & 1 & $\stackrel{0}{+}$ & 0.53 \\
\hline Intermediate & 58 & 63 & $0.84(0.67-1.04)$ & $\frac{+}{z}$ & 0.11 \\
\hline High & 107 & 153 & $0.95(0.80-1.12)$ & & 0.53 \\
\hline \multicolumn{6}{|l|}{ Planned pregnancy } \\
\hline Yes & 135 & 184 & 1 & ○ & \\
\hline No & 78 & 111 & $1.02(0.87-1.19)$ & 足 & 0.82 \\
\hline \multicolumn{4}{|l|}{ Trimester at prenatal control } & $\frac{c}{\varrho}$ & \\
\hline initiation & 198 & 50 & 1 & ¿ & \\
\hline First & 15 & 191 & $4.60(3.58-5.91)$ & & $=0.001$ \\
\hline Second & 1 & 53 & $4.87(3.79-6.25)$ & $<$ & $=0.001$ \\
\hline Third & & & & $\frac{0}{0}$ & \\
\hline \multicolumn{4}{|l|}{ Pregnancies } & $\frac{\overline{0}}{1}$ & \\
\hline$\geq 3$ & 35 & 71 & 1 & (1) & \\
\hline 2 & 80 & 96 & $0.81(0.67-0.98)$ & مـ & 0.04 \\
\hline 1 & 98 & 128 & $0.85(0.71-1.09)$ & $\vec{\sigma}^{2}$ & 0.07 \\
\hline
\end{tabular}

$p=0.04)$, in comparison with women with 3 or more pregnancies (Table 1).

The multivariate analysis indicated that women with the highest level of marginalization and without social support had significant probability of having inadequate prenatal control (Table 2).

\section{Discussion}

Since maternal-child mortality reflects the degree of social and economic development of a country, reproductive health should be a public health priority; its prevention directly depends on health services coverage and quality. ${ }^{21}$

It is necessary to recognize that an important limitation of our study was the type of sampling used for selecting the units, which didn't allow population representation to be ensured. Although controlling for factors such as obstetric risk was sought, an elevated proportion of women lacked the corresponding registry in the medical record, which demonstrates problems in technical quality of care. 
Table 2. Factors associated with inadequate prenatal control in women with social security in Mexico according to marginalization level

\begin{tabular}{|c|c|c|c|c|}
\hline Variable & Odds ratio & Standard error & p & $95 \% \mathrm{Cl}$ \\
\hline \multicolumn{4}{|c|}{ Low marginalization level } & 이 \\
\hline Unemployed & 0.89 & 0.39 & 0.8 & $0.4-2.12$ \\
\hline \multicolumn{5}{|l|}{ Marital status } \\
\hline Cohabitation & 2.95 & 1.32 & 0.02 & $1.2-7.1$ \\
\hline Single & 3.44 & 2.36 & 0.07 & $0.9-13.2$ \\
\hline Social support & 1.46 & 0.98 & 0.57 & $0.4-5.5$ \\
\hline Family dysfunction & 0.91 & 0.36 & 0.81 & $0.4-2.0$ \\
\hline Level of education & 1.9 & 0.84 & 0.15 & $0.8-4.5$ \\
\hline \multirow[t]{2}{*}{ Age } & 1.08 & 0.04 & 0.04 & $1.0-1.2$ \\
\hline & \multicolumn{3}{|c|}{ Intermediate marginalization level } & 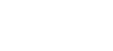 \\
\hline Unemployed & 0.85 & 0.36 & 0.7 & $0.38-1.9$ \\
\hline \multicolumn{5}{|l|}{ Marital status } \\
\hline Cohabitation & 1.38 & 0.59 & 0.46 & $0.59-3.2$ \\
\hline Single & 1.28 & 0.96 & 0.74 & $0.29-5.6$ \\
\hline Social support & 1.3 & 0.76 & 0.66 & $0.41-4.1$ \\
\hline Family dysfunction & 1.07 & 0.42 & 0.86 & $0.5-2.3$ \\
\hline Level of education & 1.58 & 0.78 & 0.35 & 0.614 .2 \\
\hline \multirow[t]{2}{*}{ Age } & 1.01 & 0.03 & 0.71 & $0.95-1.1$ \\
\hline & \multicolumn{3}{|c|}{ High marginalization level } & $\stackrel{\square}{5}$ \\
\hline Unemployed & 1.00 & 0.27 & 1.00 & $0.6-1.7$ \\
\hline \multicolumn{5}{|l|}{ Marital status } \\
\hline Cohabitation & 0.80 & 0.23 & 0.45 & $0.5-1.4$ \\
\hline Single & 0.94 & 0.40 & 0.88 & $0.4-2.2$ \\
\hline Social support & 3.53 & 1.96 & 0.02 & $1.2-10.5$ \\
\hline Family dysfunction & 0.63 & 0.17 & 0.09 & 0.4-1.1 \\
\hline Level of education & 0.91 & 0.28 & 0.76 & $0.5-1.7$ \\
\hline Age & 0.96 & 0.02 & 0.06 & $0.9-1.0$ \\
\hline
\end{tabular}

A higher proportion of women was found to a level of education of secondary school, in comparison with findings described in other investigations, where the level of education was lower. ${ }^{17}$ Women who were not marriedshowed a higher probability of inadequate prenatal care, which are results that are consistent with those from Ramírez Zetina in a Mexican population. ${ }^{20}$

The results obtained in the bivariate analysis indicated that inadequate prenatal care is associated with low income, as well as with unplanned pregnancy, which is consistent with reports in different studies. ${ }^{19,20}$

Strong association was found of the highest marginality and low economic income strata with inadequate prenatal control, which is consistent with previous results. ${ }^{20}$

Finally, it is necessary to design and implement health strategies, programs and policies focused on social determinants that enable knowing the interaction between different biological and social dimensions and the health-disease process, and to decrease health inequities by applying prenatal care successful alternative models, ${ }^{22}$ such as domiciliary visits. Group prenatal care for high-risk patients can provide more efficient and efficacious care than the traditional and predominantly medical prenatal care mode ${ }^{23}$ by promoting the creation or strengthening of social support networks, especially among 
women with higher social and economic marginalization.

\section{References}

1. Grupo de Trabajo Regional Interagencial Regional para la Reducción de la Mortalidad Materna. Reducción de la mortalidad y la morbilidad materna. Consenso Estratégico Interagencial para América Latina y el Caribe. EE. UU.: OPS; 2003

2. Cáceres-Manrique FM, Molina-Marín G. Inequidades sociales en atención materna. Rev Colomb Obstet Ginecol. 2010;61(3):231-238.

3. Observatorio de Mortalidad Materna en México. Situación actual de la mortalidad materna en México. Disponible en: http://www.omm.org.mx index.php/component/k2/item/246-situacion-actual

4. Secretaría de Salud. Norma Oficial Mexicana NOM-007-SSA2-1993 atención de la mujer durante el embarazo, parto y puerperio y del recién nacido. Criterios y procedimientos para la prestación del servicio. Diario Oficial de la Federación 1994 Oct 31. Disponible en: http://www.salud. gob.mx/unidades/cdi/nom/007ssa23.html

5. Kisuule I, Kaye DK, Najjuka F, Ssematimba SK, Arinda A, Nakitend G, et al. Timing and reasons for coming late for the first antenatal care visit by pregnant women at Mulago hospital, Kampala Uganda. BMC Pregnancy Childbirth. 2013;13(1):121.

6. Niwaru BI, Wu Z, Hemminki E. Determinants of the use of prenatal care in rural China: the role of care content. Matern Child Health J. 2012: 16(1):235-241.

7. Joshi C, Torvaldsen S, Hodgson R, Hayen A. Factors associated with the use and quality of antenatal care in Nepal: a population-based study using the demographic and health survey data. BMC Pregnancy Childbirth. 2014;14:94.

8. Andrew E, Pell C, Angwin A, Auwun A, Daniels J, Mueller I, et al. Factors affecting attendance at and timing of formal antenatal care: results from a qualitative study in Madang, Papua New Guinea. PloS One. 2014 9(5):e93025.

9. Cresswell JA, Yu G, Hatherall B, Morris J, Jamal F, Harden A, et al. Predictors of the timing of initiation of antenatal care in an ethnically diverse urban cohort in the UK. BMC Pregnancy Childbirth. 2013; 13(1):103.

10. Rowe RE, Magee H, Quigley MA, Heron P, Askham J, Brocklehurst P. Social and ethnic differences in attendance for antenatal care in England. Public Health. 2012;122(12):1363-1372.
11. Guliani H, Sepehri A, Serieux J. Determinants of prenatal care use: evidence from 32 low-income countries across Asia, Sub-Saharan Africa and Latin America. Health Policy Plan. 2014;29(5):589-602.

2. Beeckman K, Louckx F, Downe S, Putman K. The relationship between antenatal care and preterm birth: the importance of content of care. Eur J Public Health. 2013;23(3):366-371.

13. Pérez-Toga G, Sánchez-Nuncio HF, Pérez-Rodríguez $P P$, Nava-Vázquez F. Impacto del control prenatal en la morbilidad y mortalidad neonatal. Rev Med Inst Mex Seguro Soc. 2005;43(5):377-380.

14. Beauclair R, Petro G, Myer $L$. The association between timing of initiation of antenatal care and stillbirths: a retrospective cohort study of pregnant women in Cape Town, South Africa. BMC Pregnancy Childbirth. 2014; $14: 204$.

15. Hollowell J, Oakley L, Kurinczuk JJ, Brocklehurst P, Gray R. The effectiveness of antenatal care programmes to reduce infant mortality and preterm birth in socially disadvantaged and vulnerable women in high-income countries: a systematic review. BMC Pregnancy Childbirth. 2011; 11:13.

16. Faneite $\mathrm{P}$, Rivera $\mathrm{C}$, Rodríguez $\mathrm{F}$, Amato R, Moreno S, Cangemi L. Consulta Prenatal: motivos de inasistencia, ¿se justifica? Rev Obstet Ginecol Venez. 2009;69(3):147-151.

17. Coimbra L, Silva AA, Mochel EG, Alves MT, Ribeiro V, Aragão VM, et al. Factors associated with inadequacy of prenatal care utilization. Rev Saude Publica. 2003;37(4):456-462.

18. Pécora A, San-Martin ME, Cantero A, Furfaro K, Jankovic MP, Llompart V. Control prenatal tardío: ¿barreras en el sistema de salud? Rev Hosp Mat Infant Ramón Sardá. 2008;27(3):114-119.

19. Arispe C, Salgado M, Tang G, González C, Rojas JL. Frecuencia de CPN inadecuado y de factores asociados a su ocurrencia. Rev Med Hered. 2011;22(4):159-160.

20. Ramírez-Zetina M, Richardson V, Ávila H, Caraveo VE, Salomón RE, Bacardi M, et al. La atención prenatal en la ciudad fronteriza de Tijuana, México. Rev Panam Salud Pública. 2000;7(2):97-101.

21. Vega R, Barron A, Acosta L. Atención prenatal según la NOM-007 relacionada con morbilidad materna en una unidad de salud en San Luis Potosí durante 2008. Rev Fac Nac Salud Publica. 2013;3(3):265-272.

22. Medina-Gómez OS, López-Arellano O. Asociación de los tipos de carencia y grado de desarrollo humano con la mortalidad infantil en México, 2008. Cad Saúde Pública. 2011;27(8):1603-1610.

23. Krans EE, Davis MM. Strong start for mothers and newborns: implications for prenatal care delivery. Curr Opin Obstet Gynecol. 2014;26(6): 511-515. 